\title{
Tiio, Roosi, Liiso ja Toomas - maakeelseid luuletusi avaldanud Eestimaa autorite otsinguil
}

\author{
Kairit Kaur \\ Tartu Ülikooli teadur, \\ Tallinna Ülikooli Akadeemilise Raamatukogu teadur \\ kairit.kaur@ut.ee, kairit.kaur@tlulib.ee
}

\begin{abstract}
Teesid: Artiklis püütakse lahti harutada segadust, mis valitseb mõningate 1780. aasta paiku Eestimaal valminud luuletuste autorluse ümber. Nn Tiio-laulu autoriks oli A. T. Grahli väitel keegi Eestimaa daam, sama laulu Roosi-versiooni looja aga C. H. J. Schlegeli väitel "härra von Tiesenhausen Sausi mõisast". Artiklis püütakse tõestada, et Roosi-laulu taga ei olnud Ber(e)nd Heinrich von Tiesenhausen nagu seni arvatud, vaid Hans Wenzel von Tiesenhausen Sauste mõisast Rakvere lähistel, kes oli ilmselt ka 1780. aasta "Estländische poetische Blumenleses" avaldatud saksakeelse epigrammi "Der Client an seinen Sachwalter" autor, mida seni on omistatud Põhja-Lätis elanud Johann Georg von Tiesenhausenile. Selgitatakse välja ka Tiio-Roosi luuletuse adressaat - Ottilie von Tiesenhausen. Samuti püstitatakse küsimus, kas Tiio-lauluga samas noodiraamatus ilmunud Liiso-laulu avaldanud teine Eestimaa daam võis olla ka 1779. aastal "Eestimaa poeetilises antoloogias" ilmunud eestikeelsete laulude tõlkijaks. Alustatakse kaardistamist, kes need eestikeelseid luuletusi avaldanud daamid olla võisid.
\end{abstract}

Märksõnad: Ehstländische poetische Blumenlese, Andreas Traugott Grahl, luule, maakeel, naised, Hans Wenzel von Tiesenhausen, Ottilie von Tiesenhausen

\section{Sissejuhatuseks}

Esimesed maakeelsed luuletused Eesti ala naiste sulest ilmusid Johann Friedrich von Recke ja Karl Eduard Napiersky Liivi-, Eesti- ja Kuramaa üldise kirjanike ja õpetlaste leksikoni väitel juba 1779. aastal Eestimaal koduõpetajana tegutsenud Andreas Traugott Grahli Leipzigis väljaantud noodiraamatus "Oden und Lieder in Musik gesetzt" ("Oodid ja laulud muusikasse pandud", Recke \& Napiersky 1829, II: 87), millest ei ole kahjuks teada ühtegi säilinud eksemplari. Küll oli Teise maailmasõja eel uurijatele Berliini Riigiraamatukogus kättesaadav Grahli järgmine, 1784. aastal samuti Leipzigis ilmunud noodiraamat "Lieder und Handsachen für das Klavier und den Gesang" ("Laulud ja soolopalad klaverile ja laulmiseks"), kus ilmus Eestimaa daamidelt kaks laulu: "Tio, tassane ja helde" ja kevadlaul "Liesole" (Jakobson 1937: 6; Suits 
\& Lepik 1932: 153; Roos 1939: 164-165). Tiio-laulu teisend, nn Roosi-laul, trükiti 1787. aastal Põltsamaa koduõpetaja Friedrich Gotthilf Findeiseni kuueköitelise lugemiku "Lesebuch für Ehst- und Livland" ("Lugemik Eesti- ja Liivimaale") viiendas köites ja aasta hiljem, 1788, ka Saksa kirjandusajakirjas Der Teutsche Merkur (Lukas 2019: 869). Viimasele vahendas luuletuse Christian Hieronymus Justus Schlegel (1755-1842), Jenast pärit ja Leipzigis teoloogiahariduse omandanud mees, kes aastatel 1780-1782 tegutses Põhja-Eestis Karinu, Valkla ja Jäneda mõisas koduõpetajana (TLÜAR rahvusbibliograafia isikud: http:// isik2.tlulib.ee/index.php?id=739 [25.10.2021]). 1782. aasta novembri lõpus lasi ta end ordineerida ja abiellus vkj 8.12.1783 Amblas juba Valgevene Mogiljovi saksa koguduse pastorina Ambla kirikuõpetaja (kasu)tütrega; järgnevad tosin aastat tegutses ta Valgevenemaal, hiljem elas aga Peterburis, kus ka suri. (Gottzmann \& Hörner 2007, III: 1143; EEVA: https://utlib.ut.ee/eeva/index. php?lang=et\&do=autor\&aid=827 [25.02.2021].) Tema ei omista luuletust küll Eestimaa daamidele, vaid ütleb, et laulu autoriks on keegi "sakslane", "härra von Tiesenhausen Sausi mõisast", kes "tegi selle oma abikaasa surma puhul" (Zwar ist dieses Lied von einem Teutschen auf den Tod seiner Gemahlin gemacht (vom Hrn. v. Tiesenhausen auf Saus); Schlegel 1788: 422).

\section{Kes võisid olla Sausi mõisnik von Tiesenhausen ja tema õnnis abikaasa?}

Saksakeelset nime Saus või Sauß kandis Eestimaal paraku mitu mõisa. Aarne Vinkel on Roosi-luuletuse omistanud Harjumaa Sausti ehk Kaarepere (GroßSauß) mõisnikule Ber(e)nd Heinrich von Tiesenhausenile (1703-1789)(vrd EKA 1965, I: 293-294). Ilmselt toetus ta siinkohal Mihkel Kampmannile (Kampmaale), kes juba oma 1912. aastal ilmunud kirjandusloo "Eesti kirjanduseloo peajooned" esimese osa esmatrükis lk 234 väitis, et luuletuse autoriks olevat Kaarepere mõisnik, nime küll nimetamata. Selle väite võttis üle ka Villem Ridala oma 1925. aastal Noor-Eesti kirjastuses ilmunud Eesti kirjanduse ajaloos koolidele (Ridala 1924 [1925], I: 168). Kuid leidub veel teinegi Sausti või Sauste $($ Sau $\beta)$ nimeline mõis, mis asus hoopis Lääne-Virumaal Haljala kihelkonnas Sauste külas, mitte väga kaugel Rakverest ja tuleb Roosi-laulu loomiskohana samuti kõne alla, sest see mõis kuulus aastatel 1779-1781 kapten Hans Wen(t)zel(l) von Tiesenhausenile, kes ostis selle Rahvusarhiivi kinnistute registri (http://www.ra.ee/apps/kinnistud/index.php/et/kinnistud/view?id=17015 [24.10.2021]) kohaselt (kuupäevad vana kalendri järgi) 14. märtsil 1779 Hans von Wrangellilt (vt ka EAA.7.1.764, Nr. 1) ja müüs 1781. aastal kreisikohtunik Reinhold Johann von Nolckenile, viimane on märgitud Sauste mõisa omanikuna 
ka 1782. aasta hingeloenduse andmetes (EAA.1864.2.IV-4: 122v). Kinnistute registri kohaselt pani Sauste koos Tudu mõisaga avalikku müüki Eestimaa Ülemmaakohus nende omaniku Hans Wentzel von Tiesenhauseni soovil (selle kohta vt ka EAA.858.1.2152, 1. [1]). Müügitehingu kuupäevaks on registris mainitud 30.01.1781 (Tudu müüdi 6.03.1781, vt EAA.858.2.4378, pagineerimata, vt vastava kuupäevaga protokolli). Mõisad pandi müüki seoses kohtuprotsessiga, millest tuleb juttu allpool. Sellest tekkinud probleemide lahendamiseks siiski ei piisanud. Lõpuks tuli välja kuulutada ka pankrotimenetlus, mille esimene protokoll pärineb 9. juunist 1781 (vt EAA.858.2.4378). NB! Sellist kuupäeva kohtame allpool veidi teises kontekstis veel kord.

Ei ole küll kahjuks teada, millises mõisas noodiraamatu avaldaja Grahl täpselt töötas. Professor Gustav Suits on Tiio-ja Liiso-lauludega lähemalt tutvunud Jaan Roosile avaldanud arvamust, et ta tegutses kuskil Rakvere ümbruses (Roos 1939: 163; kahjuks ei paista olevat säilinud trükis ilmunud märkmeid, mis annaks lähemat aimu, kuidas Suits oma arvamuseni jõudis).

Küll on aga säilinud vihje, kelle juures Grahl töötas. 1783. aastal Tallinna kuulutustelehes oma 1784. aasta noodikogule ettetellijaid otsides allkirjastas Grahl kuulutuse A. T. Grahl, Hofmeister bey dem Herrn Hauptmann von Tiesenhausen (A. T. Grahl, koduõpetaja hauptmann von Tiesenhauseni juures; Revalische Wöchentliche Nachrichten, 21.08.1783; ära trükitud ka Heinmaa 2017: 230-231). Seega oli Grahl kindlasti Tiesenhauseni aadlisuguvõsaga seotud ja seda olid ilmselt mingil moel ka Eestimaa daamid, kelle luuletusi ta avaldas. Paraku ei too kuulutus täpset teadmist, millise hauptmann von Tiesenhauseniga oli tegemist. Indrek Jürjo on kirjutades sellest, kuidas August Wilhelm Hupel tellis 1779. aasta "Eestimaa poeetilise antoloogia" ("E(h)stländische poetische Blumenlese") oma Põltsamaa lugemisseltsile selles sisaldunud eestikeelsete aariate pärast, teinud juttu ka Grahli noodiraamatutest ja tõlkinud Hauptmann'i kapteniks (Jürjo 2004: 137). Kapteni aukraadiga olid aga nii Sauste (vt nt EAA.3.1.630: Akte in Klagesachen des Adjunkts Reinhold Johann Zoege von Mannteuffel wider den Kapitän Hans Wenzel von Tiesenhausen wegen Schuldforderung / "Toimik adjunkt Reinhold Johann Zoege von Manteuffeli võlanõude asjus kapten Hans Wenzel von Tiesenhauseni vastu”, 28.09.1776) kui ka Kaarepere von Tiesenhausenid, Kaarepere mõisnik oli lisaks veel olnud varem ka rüütelkonna peamees (Ritterschaftshauptmann) (Genealogisches Handbuch der baltischen Ritterschaften = GHbR, Teil Estland, I: 418). Kuid viide "Eestimaa poeetilisele antoloogiale" viib meid veel ühtede Tiesenhausenite juurde, kes paistavad olevat olnud seotud nii Kaarepere kui ka Sauste Tiesenhausenitega.

Nimelt on "Eestimaa poeetilist antoloogiat" lähemalt uurinud saksa kirjandusteadlane Dirk Sangmeister avaldanud arvamust, et Albrechtid trükkisid 
antoloogia 1779. aasta aastakäigu väljaandmiskohana ära Rakvere lugupidamisest Rakvere mõisniku, kohtunik Jakob Johann von Tiesenhauseni (1729-1784) ja tema perekonna vastu, kellega Sangmeister usub Albrechte olevat olnud heades suhetes, kuna Sophie Albrecht pühendas mitmeid luuletusi kellelegi Ottilie von Tiesenhausenile. (Sangmeister 2011: 422). Esimesed neist luuletustest ilmusid juba 1779. aastaks mõeldud "Blumenleses". Siin oli adressaat tähistatud küll veel initsiaalidega. Kõigepealt oli nimekujuks O. v. T-n (An meine liebe Freundin O. v. T-n. / Minu armsale sõbratarile O. v. T-nile, lk 66-71) ja seejärel T. nagu luuletuses "An meine Freundin T." / "Minu sõbratar T-le" (lk 88-90; vt Sangmeister 2011: 467; see luuletus võib siiski olla pühendatud ka ühele teisele T-tähega algava perekonnanimega sõbratarile nagu allpool näeme). Esimene luuletus ilmus nüüd juba täisnimega uuesti Sophie Albrechti 1781. aastal ilmunud esimese luule- ja näidendite kogu "Gedichte und Schauspiele" esimeses köites ("An meine Freundin Ottilie von Tiesenhausen. 1778" / "Minu sõbratarile Ottilie von Tiesenhausenile. 1778", lk 66-68), kust leiab veel kaks Ottilie von Tiesenhausenile pühendatud luuletust, millest esimese valmimisajaks on märgitud 1780 ("An meine Theure, Ottilie von Tiesenhausen. 1780" / "Minu kallile, Ottilie von Tiesenhausenile. 1780"; lk 179-180) ja teise omaks 9. juuni 1781 [sic!] ("Am 9ten Junius 1781, als ich den Tod meiner theuren Ottilie von Tiesenhausen erfuhr" / "9. juunil 1781, kui sain teada oma kalli Ottilie von Tiesenhauseni surmast”; lk 29-33). Viimased kaks luuletust on valminud juba sõbratarist eemal, sest Albrechtid lahkusid Eestimaalt septembris 1779, pöördudes järgneva aasta juulis-augustis küll veel korraks neljaks-viieks nädalaks tagasi (Sangmeister 2011: 433-434). Tundub, et 1780. aasta luuletus on omamoodi luulevormis kutse sõbratarile kokkusaamiseks. Kas kohtumine ka aset leidis, ei ole paraku teada. Viimane, 1781. aasta luuletus sisaldab aga juba teadaannet sõbratari surmast. Lisaks avaldas keegi v. Tiesenhauseni nimeline mees Albrechtide antoloogia 1780. aasta jaoks mõeldud väljaandes luuletuse "Der Client an seinen Sachwalter" ("Klient oma kaitsjale"; Estländische poetische Blumenlese für 1780 [1779]: 16).

See epigramm näib küll pärinevat pigem õiguskaitse vajaja kui pakkuja (advokaat või kohtunik) sulest ja kõlab nii:

Ich hatte, wie bekannt, wie Sie und / Alle wissen, / Mehr wie ein Rittergut, dabey ein / gut Gewissen; / Seitdem Sie meine Sache führen, / So werde, merk' ich wohl, ich beydes / noch verlieren. [Mul oli, nagu teada, nii Teile kui ka kõigile, enam kui (üks) rüütlimõis, seejuures hea südametunnistus; sest ajast kui Teie minu asja ajate, siis, nii ma panen tähele, jään ilma veel ma mõlemast.] 
Remargina: York Gotthart Mix, kes on uurinud saksa muusaalmanahhe, on pidanud selle luuletuse autoriks "endist majorit Johann Georg von Tiesenhausenit” (Mix 1987: 15, tsit. Sangmeister 2011: 422 järgi), kellele teisal omistab eluaastad 1735-1815 (Mix \& Köther \& Kandler 2018: 2), kuid selle nime ja eluaastatega mees kuulus hoopis Tiesenhausenite suguvõsa Liivimaa harru ja oli Dikḷi mõisnik, nii et vaevalt Põhja-Eestis luuletusi avaldas (vrd Hagemeister 1836, I: 111; Hagemeister 1843: 42; Paškevica 2011: 291-292).

Kaarepere mõisnikuga oli Rakvere mõisa omanik Jakob Johann seotud oma naise Wilhelmina Margarethe von Tiesenhauseni (snd von Baranoff, 1737-1808; GHbR, Teil Estland, I:402; Geni: https:/www.geni.com/people/ Wilhelmine-Margarethe-von-Baranoff/6000000004104513753 [24.10.2021]) kaudu, kes oli Bernd Heinrich von Tiesenhauseni 1774. aastal surnud abikaasa Johanna Elisabethi (snd von Baranoff; GHbR, Teil Estland, I: 418; https://www. geni.com/people/Johanna-von-Baranoff/6000000017546052447 [24.10.2021]) vennatütar. Grahliga seoses kerkib Kaarepere Tiesenhausenite puhul aga üles küsimus, miks neil oleks pidanud 1780. aasta paiku vaja minema koduõpetajat, kui 1770. aastate esimesel poolel 56aastaselt lahkunud naine ei jätnud maha alaealisi lapsi ja 1703. aastal sündinud, samuti juba eakas riigikrahv teadaolevalt uuesti ei abiellunud. Ka ei ole ei Bernd Heinrich von Tiesenhauseni ega Jakob Johann von Tiesenhauseni perekonnast teada Ottilie nimega tütart, ehkki päris välistada seda ei saa, sest Balti rüütelkondade genealoogilises leksikonis (Genealogisches Handbuch der baltischen Ritterschaften $=$ GHbR) mainitakse üht Bernd Heinrich von Tiesenhauseni noorelt surnud tütart, kelle nimi ja eluaastad ei ole teada. Küll oli Bernd Heinrichil Anna Dorothea nimeline tütar (Grahl on oma noodiraamatus Tio saksakeelse vastena andnud Dora ehk Dorothea, vt Roos 1939: 164), kuid too suri alles 1807. aastal (GHbR, Teil Estland, I: 418; https://www.geni.com/people/Anna-Dorothea-von-Tiesenhaus en/6000000007399155265 [24.10.2021])

Arhiiviallikatest nähtub, et Rakvere Tiesenhausenid olid seotud ka Sauste Tiesenhausenitega. Veel enne kui Hans Wenzel von Tiesenhausen omandas 1779. aastal Hans von Wrangellilt Sauste mõisa, rentis ta aastatel 1774 (8. aprill) 1780 (kevad) oma sugulaselt (Vetter - nii ühes Rakveres 26.04.1778 allkirjastatud kinnituskirjas (EAA.7.1.764; pagineerimata); vanaonupojalt) Jakob Johann von Tiesenhausenilt Rakvere mõisa (Gut Wesenberg; EAA.3.1.661: 1-3), st et ajal, kui Albrechtid pühendasid oma Eestimaa poeetilise antoloogia esimese väljaande Rakverele, elas sealses mõisas tõenäoliselt hoopis Hans Wenzel von Tiesenhausen oma perega. Umbes samal ajal Rakvere mõisa rentima asumisega omandas mees Tudu (Tuddo) rüütlimõisa (u 40 kilomeetrit Rakverest). Mõisa ostu kavatsust reedab 24. veebruaril 1774 Püssis väljastatud veksel Carl Adolph von Krusenstiernile (EAA.7.1.764). Paraku paistavad perekonna rahaasjad 
olevat hakanud tõsiselt allamäge minema just 1779. aastal, kui H. W. von Tiesenhausen Sauste mõisa omandas. 1780. aasta 20. märtsil andis Jacob Johann von Tiesenhausen eelmise aasta eest saamata jäänud rendi tõttu oma sugulase kohtusse (EAA.3.1.661: 2), 1781. aastal kuulutati välja Hans Wenzel von Tiesenhauseni pankrott (EAA.858.2.4378). Kuna mõlemad omandusse ostetud mõisad olid omandatud laenuraha eest, mille saamiseks oli kapten von Tiesenhausen väljastanud palju veksleid, siis nende väljalunastamiseks tuli mõisad maha müüa: loobuda tuli nii Saustest kui Tudust. Viimase omandas Rahvusarhiivi kinnistute registri järgi Heinrich Johann von Wrangell kahe peale kellegi teisega (http://www.ra.ee/apps/kinnistud/index.php/et/kinnistud/ view?id=17031 [25.10.2021], register toetub toimikule EAA.4187.1.3796). H. J. von Wrangell on mõisa omanikuna märgitud ka 1782. aasta hingeloendis (EAA.1864.2.IV-5: 83v). Toimikust EAA.4187.1.3796 (vt mapp Tuddo No 19) ilmneb, et mees kellega kahasse mõis omandati, oli ülalmainitud Carl Adolph von Krusenstiern, kes mõisa kahe aasta jooksul H. J. von Wrangellilt välja ostis ja 1783. aastal selle omanikuks sai (Wrangellile jäi küll raieõigus Tudu metsas). Hans Wenzel von Tiesenhauseni pankrotiprotsess koos võlgade tasumisega paistab olevat kestnud 1789. aastani (EAA.858.2.4378).

See lugu sobiks hästi Andreas Traugott Grahli eluloo teadaolevate faktidega: juhul kui Grahl töötas koduõpetajana Hans Wenzel von Tiesenhauseni juures, siis oli tal 1783. aastal tõepoolest arukas otsida lisasissetulekuid raamatu väljaandmise abil, hiljemalt 1786. aastal suundus ta aga Venemaale Moskvasse, sest sellest aastast pärineb tema käsikirjaline noodiraamat motettidega vene keeles (Roos 1939: 164). Samuti sobiks see Gustav Suitsu oletusega, et Grahl tegutses Rakvere kandis.

See pankrotilugu viib ka mõttele, et vähemasti 1780. aastale pühendatud Albrechtide antoloogias luuletuse avaldanud v. Tiesenhausen oli just nimelt Hans Wenzel ja ehk oli hoopis tema pere see, kellest inspireerituna Albrechtid 1779. aastal Rakvere nime oma esimese Eestimaa luulealmanahhi tiitellehel jäädvustasid. Kus Sauste Tiesenhausenid pärast pankrotti elasid, ei ole selge. Enne Tudut ja Saustet kuulus neile küll ka veel Saarnakõrve (Sarnakorb) mõis Kose kihelkonnas Harjumaal, mille Hans Wenzel omandas 1770. aastal (vt Rahvusarhiivi kinnistute register http://www.ra.ee/apps/kinnistud/index. php/et/kinnistud/view?id=16631 [25.10.2021] ja EAA.858.1.1478: 11-15, 16), mida pankrotiprotsessis ei mainita, kuid ka see mõis on hiljemalt 1782. aasta hingeloenduse ajaks kuulunud uuele omanikule (Gustav Reinhold von Payküll; EAA.1864.2.IV-1: 432). Ehk läks see müüki juba seoses Tudu omandamise või Rakvere mõisa rendi tasumisega. Võib-olla kuulus see aga nende väiksemate mõisate hulka, mille ostu-müüki mainib Hans Wenzel von Tiesenhausen nimesid nimetamata 26. juunil 1781 Eestimaa ülemmaakohtule esitatud aru- 
andes "Demüthigste Anzeige und Unterlegung der wahren Umstände meines gegenwärtigen unglücklichen und betrübten Schicksaals" ("Minu praeguse õnnetu ja kurva saatuse tõeliste põhjuste kõige alandlikum teadaanne ja tõlgendus"), kus ta annab aru oma kurvast saatusest ja püüab tuua tõendeid, et ta ei tõmmanud võlausaldajaid oma õnnetusse kaasa sihilikult (viimane dokument toimikus EAA.858.1.2152). Siit ilmneb, et tema karjäär mõisaomanikuna sai alguse Lautna mõisa omandamisega oma isalt, mille ta peagi müüs, millele järgnesid mitmed ostu-müügi tehingud (EAA.858.1.2152, Demüthigste Anzeige, 1. [1v].). Siit ilmneb ka, et veel enne Rakvere mõisa asus ta rentima Lagedi (Laack) ja Saha (Sage) “avalikke” mõisu (publique Güter) Harjumaal (Demüthigste Anzeige, 1. [2]), kuid rendileping nende osas lõppes umbes samal ajal Rakvere mõisaga, 1780 (Demüthigste Anzeige, 1. [4]). Lisaks olid Hans Wenzel von Tiesenhausenile kuulunud kolm korterit Rakveres (Demüthigste Anzeige, 1. [4v]). Kas ka neist tuli loobuda, aruandest ei selgu.

On ka võimalik, et pere oli pärast mõisate kaotamist korteris Tallinnas: Hans Wenzeli õe Sophie mehele Sten Göran von Mandersternile (Manderstjernale) kuulus 1781. aastal korter Toompeal, mis oli u 1772-1774 kuulunud Hans Wenzel von Tiesenhausenile, kuid jõudis õemehe omandusse seoses Tudu ostuga (vt EAA.858.1.2152, Demüthigste Anzeige, 1. [3v]). Tallinnaga paistab Hans Wenzel olevat lähedalt seotud. Tema isa oli Balti rüütelkondade genealoogilise leksikoni andmeil Tallinna ülemkomandant [1744-1769], kindralleitnant Fabian Georg von Tiesenhausen (1715-1769) (GHbR, Teil Estland, I: 416). Hans Wenzel ehk täisnimega Hans Wenzislaus Johannes Nepomuk Thaddeus Judas Benedictus Hugo von Tiesenhausen oli Läänemaalt Lautnast pärit Fabian Georgi ja tema Böömimaalt, Austria juurtega suguvõsast pärit abikaasa vabaproua Anna Josephine Hildprandt (või Hildebrandt) von und zu Ottenhauseni teine poeg (muide, Wenzel või Wenzislaus on Böömimaa kaitsepühak, keda tšehhid kutsuvad Václaviks). Kus ja millal Hans Wenzel täpselt sündis ei ole teada ei Balti rüütelkondade leksikonile ega ka nt Genile (vt https://www. geni.com/people/Hans-Menzislaus-von-Tiesenhausen/6000000079602448005 [26.10.2021]; NB! Genis eesnimi vigasel kujul). Arvestades, et tema vanem vend sündis aastal 1745, võib arvata, et ta sündis aasta-paar hiljem ning oli 1780. aasta paiku umbes kolmekümnendate eluaastate algupooles või keskpaigas. Vend Jakob Joseph Maria, samuti kapten ning Paatsalu, Illuste, Pivarootsi, Voore ja Vana-Virtsu mõisnik (GHbR, Teil Estland, I: 416-417), ristiti Tallinna Toomkoguduses (TLA.237.1.23: 207 ja TLA.237.1.26: 225, Nr. 3778). Selle koguduse liige oli ka õde Natalie Margarethe (TLA.237.1.26: 226, Nr. 3803), kes abiellus siin 1763. aastal Eestimaa asekuberneri ja Tallinna komandandi kindralleitnant Joachim von Siversiga (GHbR, Teil Estland, I: 416). Mis sai õest pärast tema abikaasa surma 29.12.1778 siit paraku ei selgu. 
Ka Hans Wenzeli enda kohta siit märget ei leia, samuti nagu Niguliste või Oleviste meetrikatest ega ka Kirbla või Lihula kihelkonna kirikuraamatutest, mille lähistele Lautna jäi (viimaseid ei ole sellest perioodist säilinud). Ei ole teada ka tema surma-aasta.

Paraku ei oska rüütelkondade leksikon öelda ka midagi tema naise kohta. Tema nimeks on märgitud teadmatust tähistav N.N., abiellumise kohta on märgitud, et see toimunud Poolas (GHbR, Teil Estland, I: 416). Juhul kui Hans Wenzeli abikaasa oli Sophie Albrechti luuletuste adressaat, siis pidi see naine surema ajavahemikus umbes september 1779 (mil Albrechtid Eestimaalt lahkusid) kuni 9. juuni 1781, millega on dateeritud Sophie Albrechti järelehüüe. Tõenäolisem tundub ta surm pärast 1780. aasta augustit, mil Albrechtid veel kord Eestimaad väisasid; sel ajal paistab naine veel elus olnud olevat, vähemasti mingeid kuuldusi tema surmast Sophie Albrechtini suvise Eestimaa-külastuse käigus ilmselt ei jõudnud. Võib arvata, et ta suri veidi enne 1781. aasta 9. juunit, esimesest leinast üle saanuna andis Hans Wenzel von Tiesenhausen ilmselt oma abikaasa surmast Sophie Albrechtile teada (või tegi seda keegi ühistest tuttavatest) ja algatas seejärel ka pankrotiprotsessi (või tegid seda võlausaldajad?); NB! Sophie Albrechti luuletuse 9. juuni on kalendrierinevuste tõttu (Saksamaal kehtis uus, nn Gregoriuse kalender) 11 päeva võrra varasem kui pankroti algatamise kuupäev (Eestimaal kehtis Juliuse kalender), nii et mai lõpuks 1781 oli naine ilmselt juba surnud.

Et naine juunis 1781 tõepoolest juba surnud oli, selgub Hans Wenzel von Tiesenhauseni 26. juunil 1781 esitatud "Alandliku aruande" lisast, kus ta mainib naist, kahjuks nimeta, kolmel korral. Kõigepealt seoses oma vanema venna Jacob Josephiga, kes tasus ta eest Lagedi ja Saha maksmata jäänud rendi, et säästa Hans Wenzeli naise tervist:

Nur ein zährtlicher Bruder konnte mit mir zu gleich das empfinden, was ich armer Mann damals empfand, da ich eine kränckliche Frau, die nunmehro nicht mehr unter der Zahl der Lebendigen und Leidenden ist, die meine gantze Glückseeligkeit des Lebens aus machte, für Schrecken und jede Gemüthsbewegung in Acht zu nehmen hatte. Mein guter Bruder kannte die Zährtlichkeit mit der ich meine Frau liebte; erkannte zugleich ihre schwache Gesundheit und empfindsahmes Gemüthe, und alles dieses verband ihn zu thun als ein jeder Bruder zu thun schuldig ist.

Vaid õrn vend suutis minuga võrdselt tunda, mida ma vaene mees tollal tundsin, sest pidin haiglast naist, kes nüüdseks enam elavate ja kannatajate hulgas ei viibi, kes oli mu elu kogu õnn, säästma igasuguse hirmu ja meeleliigutuse eest. $\mathrm{Mu}$ vend tundis õrnust, millega ma oma naist 
armastasin: tundis samas ära tema nõrga tervise ja tundelise loomu, ja see kõik ajendas teda tegema, mida iga vend on kohustatud tegema. (EAA.858.1.2152, Demütigste Anzeige, 1. [6v/7])

Teisel korral on naisest juttu seoses tõlla müügiga, millest tuli loobuda seoses protsessiga Jakob Johann von Tiesenhauseniga:

Eine zweisässige Kutsche mußte ich an den Herrn Jacob Krause für $80 \mathrm{Rb}$ verkaufen, um die leztere Querel wieder meinen Gegner den Herrn Baron $v$. Tiesenhausen zu prosequiren. Ob ich gleich alles that um jede gerichtliche unangenehme Handlung und jede bedrohende Sequestration zu vor zu kommen, damit ich eine Frau beruhigte die meinem Hertzen so theuer und meiner häußlichen Glückseeligkeit so nothwendig war; so wurden doch alle meine Wünsche, Bemühungen und Hofnungen vereitelt.

Ühe kahekohalise tõlla pidin 80 rubla eest härra Jacob Krausele müüma, et viimases tülis härra parun von Tiesenhauseni vastu hageda. Kuigi tegin kõik, et ennetada igasugust kohtulikku ebameeldivat protsessi ja iga ähvardavat konfiskeerimist, et rahustada oma naist, kes oli mu südamele nii kallis ja mu kodusele õnnele nii vajalik; siis läksid kõik mu soovid, püüdlused ja lootused tühja. (EAA.858.1.2152, Demütigste Anzeige, 1. [7])

Viimaks oli mees vallasvara sunnitud müüma juba seoses naise põetamise ja matusekuludega:

Die übrigen Meubeln, als Schildereyen, ein Dutzend Stühle, ein Canapé, etwas Bett und Leinen Zeug habe ich verkauft, mit dem Gelde meiner seel. Frau in Ihrer Kranckheit Bequemlichkeit und Hülfe zu schaffen gesucht, und mit dem Reste nach ihrem seel. Tode den Arzt und die Apotheke bezahlt, wie auch die Beerdigungskosten bestritten.

Ülejäänud mööbliesemed nagu pildid, tosin tooli, üks kanapee, veidi voodipesu ja linast kangast müüsin maha, püüdes oma õndsale naisele tolle haiguses mugavust luua ja abi hankida, ja ülejäänuga maksin pärast tema õnnist surma arstile ja apteegile ning tasusin matusekulud. (EAA.858.1.2152, Demütigste Anzeige, 1. [7-7v])

Juhul, kui naine oli Toomkoguduse liige, ei ole tema surmast jälge maha jäänud, aastatest 1776-1792 sellest kogudusest meetrikaraamatud puuduvad, ka ei paista teda mainitavat 1913. aasta väljakirjutistes. Sama ebameeldiv 
on uurija seisukohalt olukord Haljala kirikuraamatutega, mille alla Sauste mõis kuulus: need puuduvad aastatest 1772-1789. Ka Viru-Jaagupi kiriku meetrikatest (EAA.3114.2.3), mille alla kuulus Tudu mõis, Hans Wenzel von Tiesenhauseni pereliikmete nimesid ei paista, samuti Kose kiriku meetrikatest (EAA.1215.2.5), mille alla kuulus Saarnakõrve. Igatahes oleks huvitav teada, kas Saarnakõrve kuulus Hans Wenzeli perekonnale veel ajal, kui Albrechtid 1776. aastal Kose kihelkonda Palvere mõisniku von Manteuffeli teenistusse tulid (see mees oli muide tuntud Ravila krahvi ja eesti rahvast "ajaviite peergo valgel” oma juttudega lõbustanud Peter von Manteuffeli isa), ja kas Palvere mõisnik ja hilisemad Sauste Tiesenhausenid suhtlesid juba ajal, mil Tiesenhausenid veel Kose kihelkonnas elasid, või tutvusid Albrechtid ja Tiesenhausenid mingil muul moel, nt Palvere mõisniku Tallinna residentsis, kus Johann Friedrich Ernst Albrecht ka kindlasti töötas (Sangmeister 2011: 430-431).

Huvitav on see, et üks väheseid kordi, kui tõenäoliselt Hans Wenzeli naine on jäädvustunud meie kirikuraamatutes, kahjuks taas eesnimedeta, on seotud just Ottilie-laadi nimega. Nimelt on Rakvere koguduse meetrikas aastatest 1772-1795 leidnud kapteniproua Tiesenhausen äramärkimist kolmel korral: kõigepealt 12. juunil 1777 kirurg Gotze (või Götze) tütre Ottiliana Amelie kõige esimese vaderina (EAA.3057.2.2: 34v), siis 8. septembril 1777 tisler [Thomas Michael] Nordeni poja Gabriel Ernsti ristivanemana (EAA.3057.2.2: 35) ja seejärel sama aasta 8. novembril parun Clodti ja tema abikaasa, neiupõlvenimega Schwengel[m?] tütre Amalia Elisabethi vaderina (EAA.3057.2.2: 35). Siin on ilmselt tegemist Kloodi (Peuth) mõisniku Adolph Friedrich Cloth von Jürgensburgi (1738-1806; GHbR, Teil Estland, I: 40) ja tema abikaasa Jakobine Henriette (snd von Schwengelm, 26.07.1752-21.02.1779; GHbR, Teil Estland, II: 256) tütrekese Amalia Elisabethi (1777-1778) ristimisega (https://www.geni.com/people/AmaliaElisabet-Clodt-von-J\%C3\%BCrgensburg/6000000081819854835 [29.10.2021]).

Tegemist võib olla juhusega, kuid mõnikord anti ristilapsele üks või mitu ristivanema eesnimedest; Sophie Albrechti adressaadi eesnimi võis seega Ottilie resp. Ottiliana kõrval või asemel olla ka Amelie või Amalie, millest kõlasarnasusest tõukudes võidi sõbratari teatavaks anonümiseerimiseks tuletada Ottilie (ehk oli Hans Wenzeli naine kuidagi seotud ka mehe emapoolse Ottenhausenite suguvõsaga?); igatahes paistab Sophie Albrecht olevat muudetud eesnime kasutanud ühe oma teise aadlisoost adressaadi puhul, keda ta nimetab Ernestine von Hastferiks, kuid selle eesnimega naist balti rüütelkondade genealoogilisest leksikonist vaadeldavast perioodist ei leia; samas teist aadlikust adressaati, Helene von Bielskyt on ta nimetanud õige eesnimega (nende daamide kohta vt lähemalt allpool). Saksa nimi Ottilie on üheks püha Odilia nimekujuks, mille lühendvormide seast võib leida ka sellised nagu Tilla, Tilly, Tilia või Tillie, mida võidi kasutada pereliikme hellitusnimena, millest eestikeelse luuletuse 
looja võis kõlasarnasuse põhjal tuletada kuju Tiiu, millele saksa helilooja võis anda selgituseks selle tavapärasema vaste Dora või Dorothea. Hans Wenzel von Tiesenhauseni abikaasa võimaliku eesnimena jääb ristilaste nimevaliku põhjal valimisse ka Elisabeth, mille vasteks oleks Liiso.

Meie uurimuse seisukohast on eriti huvitav, et Jakobine Henriette von Schwengelmi vend Georg Wilhelm von Schwengelm (1740-1794) oli Valkla ja Jäneda mõisnik (GHbR, Teil Estland, II: 256, 257), kelle juures ajakirjale Der Teutsche Merkur Roosi-luuletuse vahendanud C. H. J. Schlegel oli koduõpetajaks (vt eespool). Igatahes kinnitab Rakvere kirikuraamatu sissekanne, et Sauste Tiesenhausenid käisid Schwengelmitega läbi. Sedakaudu võis Roosi-laul ka Schlegelini jõuda. Kahte mõisnikku sidus sarnane elukogemus ja ühised lähedased inimesed - Georg Wilhelm von Schwengelm oli 1770. aastal kaotanud 22-23aastase abikaasa, kes suri pärast sünnitust ja 1779. aastal 26aastase õe, kes oli Hans Wenzel von Tiesenhauseni abikaasa sõbratar; Hans Wenzel oli 1781. aastal pidanud matma ilmselt samuti pigem noore abikaasa. Ühendlüliks kahe perekonna vahel oli ka Tudu mõis, mis kuulus 1772. aastani Georg Wilhelmi ja Jakobine Henriette isale, maanõunik Jakob Heinrich von Schwengelmile, kes müüs selle Carl August von Bergile (vt Rahvusarhiivi kinnistute register, mis toetub arhivaalile EAA.858.1.1423). Tollelt ostis mõisa ilmselt õemees Manderstern, kellelt Hans Wenzel mõisa omandas (EAA.858.1.2152, Demüthigste Anzeige, 1. [3v]) Paraku ei ole ma seni suutnud leida midagi Hanz Wenzel von Tiesenhauseni ja tema abikaasa endi laste kohta, kes võinuks vajada Grahli-sugust koduõpetajat.

\section{Tiio või Roosi - kumb on kana, kumb on muna ja kes on autorid?}

Kuidas võisid Tiio- ja Roosi-luuletuste tekkelood seotud olla? Kumb on kana, kumb on muna? Hans Wenzel von Tiesenhausen ilmselt luuletas, aga kas ka eesti keeles? Kuna Tiio-laul ilmus varem, tunduks tõenäolisem, et Tiio-laul oli varasem. Nii selged asjalood siiski ei ole. Recke ja Napiersky leksikoni väitel ilmusid kellegi Eestimaa daami luuletused juba Grahli 1779. aasta noodiraamatus, kuid mul ei ole siiani kuskilt õnnestunud leida allikat, mis täpselt kirjeldaks, millised eestikeelsed laulud selles kogumikus esindatud olid. Samas ei paista Recke ja Napiersky midagi teadvat Grahli 1784. aasta noodiraamatust; ei saa välistada, et info Eestimaa daami luuletuste kohta oli jõudnud nendeni kuulu teel ja nad seostasid selle neile teadaoleva noodiraamatuga (Recke ja Napiersky toetusid allikana Meuselile, viidatud lehekülge arvestades ilmselt tema saksa õpetlasleksikoni "Das gelehrte Teutschland" 1796. aasta 5. trüki 
2. köitele, kuid siin ei ole tõesti 1784. aasta väljaannet nimetatud; samuti ei seisa siin midagi Eestimaa daamidest, vt Meusel 1796, II: 634). Täie kindlusega teame Tiio-laulu esinemist aga just alles 1784. aasta Grahli noodiraamatus. Eestikeelseid laule (ein paar ehstnische Lieder) mainib Grahl juba oma kuulutuses 1783. aasta augustist; võib arvata, et selleks ajaks olid nii Tiio- kui Liiso-laul ilmselt juba tema käsutuses ja viisistatud. Kuigi Roosi-laul ilmus eri versioonides 1787 ja 1788, pidi see valmima kindlasti varem, kuna Schlegel lahkus Eestimaalt 1783. aastal: arvestades Hans Wenzeli naise oletatava surmaajaga 1781. aasta paiku tundub tõenäoline, et laulu algne variant võis valmida veel enne Schlegeli lahkumist, ehk isegi ajal, mil ta oli veel koduõpetaja, seega enne 1782. aasta novembri lõppu. Kuna Schlegel seostas härra von Tiesenhausenit veel Saustega, siis ehk koguni veel varem, juba 1781. aastal. Eelneva põhjal võiksime oletada, et laul oli olemas kõigepealt pikas Roosi-laulu versioonis, nagu see ilmus 1788. aasta Teutsche Merkuris. Samas pole selge, kas Schlegel sai laulu juba peagi pärast naise surma või vahetult enne lahkumist 1783. aasta detsembris. Kindlasti oli Roosi-laulu varasem, kuid hiljem trükki jõudnud versioon olemas juba 1783. aastal. See nähtub Schlegeli 1788. aasta artikli alapealkirjast. Nimelt on artikli pealkirjale "Etwas über Form, Geist, Charakter, Sprache, Musik und Tanz, der Ehstnischen Nation. Beyläufig etwas über die Schönheit der teutschen Damen in Ehstland" ("Üht-teist eesti rahvuse vormist, vaimust, iseloomust, keelest, muusikast ja tantsust. Muu hulgas mõnda Eestimaa saksa daamide ilust") lisatud märkus "ühele sõbrale aastal 1783" (An einen Freund im Jahr 1783). Paraku me ei tea, kas see kirjutis valmis enne või pärast augustit 1783. Ehk kärpis Grahl luuletust viisistamise eesmärgil ja otsis ka avaldamiseks meloodiaga paremini sobituvat sõnastust; luuletuse hiljem Findeiseni ajakirjas trükkida lasknud isik pöördus aga hiljem osalt algsema sõnastuse juurde tagasi, säilitades küll kärbitud vormi. Nimi Tio viitab, et Tiio-laul võis olla pühendatud samale isikule kui Sophie Albrechti järelhüüde Ottilie von Tiesenhausen. Kuid nagu kirikuraamatutest näha, oli Tiiu (kujul Thio või Tio) tollal eesti naiste seas üsna levinud nimi, nii et Eestimaa daamile võis see olla lihtsalt üks üldistunud eesti/kohaliku naise nimi, millel konkreetne seos luuletuse adressaadi nimega puudus.

Usku, et Tiio-laul ilmus esmakordselt just 1784. aastal, lisab Findeiseni ajakirjas avaldatud esimene, ilmumisaastalt varasem Roosi-laulu versioon. Nimelt on luuletuse 1787. aastal avaldada lasknud anonüümne isik öelnud selle eel: "Eesti laulukese, millesse on lipsanud liiga palju vigu, lasen teist korda ära trükkida." (Das Ehstnische Liedchen, in welches zu viele Fehler eingeschlichen, lasse ich zum zweytenmal abdrucken; Minno Römuks olli Rosi 1787: 472). Sellega on öeldud, et laul on trükis ilmunud varem vaid üks kord (seega, juhul kui tegemist on sama lauluga, siis 1784. aasta eel (nt 1779) see ilmselt trükis ilmunud ei olnud). Sarnaselt 1784. aasta Grahli kogumiku Tiio- 
lauluga on sel Roosi-laulu versioonil kolm salmi ja sellelegi on lisatud noodid. Trükkiandja pole küll helilooja nime maininud ja ütleb vaid: "Vaske lõigatud meloodia on sõpruse kingitus." (Die in Kupfer gestochne Melodie ist Geschenk der Freundschaft; Minno Römuks olli Rosi 1787: 472). Kahjuks puudub võimalus võrrelda, kas viis on identne Grahli kogumikus ilmunuga. Huvitav on ka, et laulu trükkiandja ei toonita, et on selle autor.

Tabel 1. Tiiu-laul (1784) ja Roosi-laulu versioonid (1787, 1788)

\begin{tabular}{|c|c|c|}
\hline $\begin{array}{l}\text { Tio tassane ja helde } \\
\text { Olli armas minnole } \\
\text { Pea öitsis pea näertsis } \\
\text { Näertsis jöudis surmale. }\end{array}$ & $\begin{array}{l}\text { Minno Römuks olli Rosi } \\
\text { Römuks oma Wennale, } \\
\text { Eile öitsis, tänna närtsis } \\
\text { Närtsis, jõudis Surmale. }\end{array}$ & $\begin{array}{l}\text { Minno romo olli Rosi } \\
\text { Römaks oma Wennale } \\
\text { Pea oitsis pea närtsis, } \\
\text { Närtsis judis surmale }\end{array}$ \\
\hline 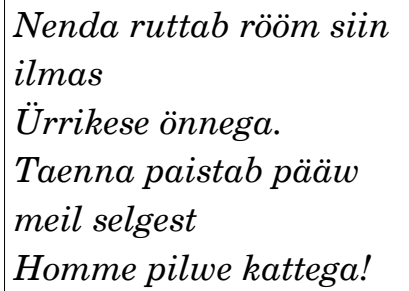 & $\begin{array}{l}\text { Nenda on need Ilma } \\
\text { Römud } \\
\ddot{U} r r i k e \text { on nende Önn. } \\
\text { Tänna paistab Pääw } \\
\text { meil selgest, } \\
\text { Homme Pilwed kattawad. }\end{array}$ & $\begin{array}{l}\text { Menda on need ilmsed } \\
\text { römud } \\
\text { Irrikdenn' on nende ön } \\
\text { Tänna paistal pän meil } \\
\text { Selgest } \\
\text { Homme pilwed kattawad }\end{array}$ \\
\hline $\begin{array}{l}\text { Agga Tio öitseb jälle } \\
\text { Sure Issa rohho'as! } \\
\text { Joua aegja wi mind senna } \\
\text { Kus meid surm ei } \\
\text { lahhuta. }\end{array}$ & $\begin{array}{l}\text { Minno Rosi öitseb jälle } \\
\text { Sure Issa Rohho A'as } \\
\text { Joua aeg,jawi mind senna } \\
\text { Kus meid Surm ei } \\
\text { lahhuta. }\end{array}$ & $\begin{array}{l}\text { Minno rosi oitseb jälle } \\
\text { Sure issa rohhoajas } \\
\text { Ioua aeg wi mind sinna } \\
\text { Kus ei surm meid } \\
\text { lahhutab; }\end{array}$ \\
\hline $\begin{array}{l}\text { Grahl } 1784 \text { (tsit. Suits } \\
\text { \& Lepik 1932: } 153 \text { järgi) }\end{array}$ & $\begin{array}{l}\text { Findeiseni Lesebuch für } \\
\text { Ehst- und Livland 1787, } \\
\text { V: } 472\end{array}$ & $\begin{array}{l}\text { Ia se mötte rosi peäle } \\
\text { Lühhendago meie aeg } \\
\text { Löpwad otsa meie römud } \\
\text { Oh siislöppeb kurbaduska. } \\
\text { Kerge muld se katko kinni } \\
\text { Sedda kallest pörmokest } \\
\text { Lilled öitske haua peale } \\
\text { Oepik laulgo haledast. } \\
\text { Schlegel 1788, Der Teut- } \\
\text { sche Merkur, II: } 421\end{array}$ \\
\hline
\end{tabular}


Schlegel on kõigile viiele salmile Teutsche Merkuris lisanud proosavormis saksakeelse tõlke. See oli eesti keelt mitteoskavat saksa lugejat arvestades muidugi vajalik, kuid siit tõukudes võib tõstatada vähemasti teoreetiliselt küsimuse, ega eestikeelsele laulule mõnd saksakeelset versiooni ei eelnenud, olgu luules või proosas. Sel juhul oleks võimalik, et tekstil on tõepoolest autoreid enam kui üks. Kõigepealt see, kes saksakeelse versiooni luuletas/kirja pani, nt Sauste mõisnik või koduõpetaja (antud juhul siis ilmselt Grahl, kelle roll võis piirduda siiski ka vaid helilooja omaga), seejärel aga selle eestindanud isik (keegi Eestimaa daam). Just koduõpetajad kirjutasid sageli juhuluuletusi nagu kõnealune leinaluuletus. Euroopa raamatukogude ja arhiivide personaalse juhuluule käsiraamatu Tallinna ja Tartu köidete põhjal sellele sündmusele pühendatud saksakeelset juhuluuletust siiski säilinud olevat ei paista (vt Handbuch des personalen Gelegenheitsschriftums 2003a ja 2003b). Võimalik on ka, et tekst loodigi kohe eesti keeles, kuid seda redigeeris keegi teine kui selle looja: kas Eestimaa daam mõisniku teksti või mõisnik, kelle naine oli luuletuse adressaat, kirjutas üle Eestimaa daami teksti, muutes selle soolisustatumaks, rääkides meesvaatepunkti rõhutamiseks endast kui "vennast", lähtudes võib-olla mingist kristlikust konventsioonist rääkida meestest ja naistest kui õdedest ja vendadest Jumalas (pietistliku või vennastekoguduse kirjanduse mõju?). Ühel Eestimaa daamil oleks selles võtmes alustada olnud küll pisut kummaline, temale sobiksid pigem Tiio-laulu sooneutraalsed algusread. Samas toob juba "Eesti kirjanduse ajalugu" (EKA 1965, I: 293) esile, et abikaasa asemel on Roosi-laulus juttu õest. Kas on olemas variant, et Schlegel eksis ja luuletus oli algselt pühendatud siiski just õele? Hans Wenzelil oli kolm õde, kuid üks neist, Katharina Alexandra, maeti juba 1751. aastal ja teine, Sophie, abielus v. Manderstjerna, suri alles 1803 (vrd GHbR, Teil Estland, I: 416). Teame ülalt, et üks õde oli Hans Wenzelil veel, Natalie Margarethe, kes Joachim von Sieversi surma järel leseks jäi. Tõenäoliselt abiellus ta uuesti, sest "Alandlikus aruandes" mainib Hans Wenzel oma teise õemehena "assessor v. Bruemmerit" (EAA.858.1.2152, Demüthigste Anzeige, 1. [6]). Assessoriks on nimetatud Peter Engelbrecht von Brümmerit, kellele kuulus 1786. aastal Saarnakõrve mõis (vt Rahvusarhiivi kinnistute register http://www.ra.ee/apps/kinnistud/index.php/ et/kinnistud/view?id=16631 [01.11.2021]). Kaks perekonda tõesti suhtlesid tihedalt. Nagu selgub Toomkoguduse meetrikast, oli 1.04.1747 sündinud Peter Engelbrecht von Brümmeri üks ristiisadest Hans Wenzeli isa (Obrist-Lieutenant $v$. Tiesenhausen, vt TLA.237.1.23: 215). Balti rüütelkondade leksikon mainib Peter Engelbrechti abikaasana siiski vaid Martha von Rosenit, kelle eludaatumiteks antakse 18.03.1748-15.02.1785 (GHbR, Teil Livland I: 344), kuid Geni nimetab Martha kõrval eraldi veel teistki nime, Margaretha von Brümmer (vt https://www.geni.com/people/Peter-Engelbrecht-von-Brummer- 
Erbin-von-Rosenhof-a-Sompah/6000000010260339000 [01.11.2021]), peab aga kaht naist identseks ja omistab Margarethele Martha eluaastad. Kas võis olla, et Martha, kellega Peter Engelbrecht abiellus 1770. aastal (vt EAA.1226.2.4: 22p) ja kellega tal oli mh lapsi, kes kandsid Ottiliana ja Wenzeli nime, suri juba umbes 1780 ja Peter Engelbrecht abiellus 1781 uuesti, nüüd oma ristiisa tütrega? Sellele hüpoteesile räägib siiski vastu see, Peter Engelbrechti noorima poja emana on 1782. aastal Jõhvi kirikuraamatus märgitud endiselt Martha von Rosen (EAA.1226.2.6: 16p). Seega puudub hetkel selgus, kes oli mainitud assessor von Brümmer. Samuti ei tea me, millal Nathalie Margarethe suri ja seetõttu ka mitte, kas ta tuleb kõne alla luuletuse adressaadina. Kas luuletus võis algselt olla pühendatud Georg Wilhelm von Schwengelmi õele? Sel juhul võis ka luuletus valmida juba 1779. aastal, kuid et Findeiseni ajakirjas on juttu teistkordsest avaldamisest, siis trükis see ilmselt enne 1784. aastat ei ilmunud. Kui luuletus oli tõesti pühendatud õele, kaovad muidugi igasugused nimelised paralleelid ja algne adressaat erines Sophie Albrechti omast. Mäng nimedega võis sel juhul lähtuda lihtsalt näiteks katsest leida meloodiaga sobivamat nimevormi või mängiti alliteratsiooni ja algriimiga (Tio-tassane; römuks/romoRosi), et jäljendada eesti rahvalaulu vormikonventsioone; roos-Roosi arendas järjekindlamalt luuletuses kasutusel olnud lille kasvamise-närtsimise-taastärkamise kujundit, mis võib olla põhjuseks, miks selle juurde tagasi pöörduti. Muidugi võis aset leida ka samale luuletusele uue funktsiooni andmine teise samalaadse sündmuse jaoks (algselt õe või õdede surmale pühendatud teksti muudeti mõnevõrra naise surma järel). Näiteid sellise ümberadresseerimise kohta baltisaksa juhuluulest 18. sajandist leiab (vt Kaur 2013: 119). Mis ei muuda tõsiasja, et autoreid või teksti vormijaid võis Tiio- ja Roosi-laulul olla siiski mitu, sh keegi Eestimaa daam.

\section{“Tomas ja Liso" ning "Liesole" - seotud tekstid?}

Kui 1779. aastal Tiio-laul arvatavasti siiski trükki ei jõudnud, siis kust võisid Recke ja Napiersky tulla mõttele, et ühe Eestimaa daami luuletused sel aastal ilmusid? Kas Grahli 1779. aasta noodiraamatus võis olla ilmunud Eestimaa daami(de)lt teisigi eestikeelseid luuletusi? Kahjuks puudub meil võimalus seda väidet otseallikast kontrollida. Või tõi Läti alal tegutsenud baltisaksa leksikonikoostajad aasta 1779 juurde mõni muu mõtteuid? Näiteks kuskilt nendeni jõudnud teadmine, et 1779. aastal eestikeelsed laulud tõepoolest ilmusid, mille nad siis seostasid mingil muul teel nendeni ulatunud teabega, et Eestimaa daamid avaldasid eestikeelseid tekste mingis Grahli noodiraamatus? Kolm maakeelset teksti ilmus anonüümselt 1779. aastal tõesti, juba mainitud "Eesti- 
maa poeetilise antoloogia” 1779. aastale pühendatud aastakäigus. Liina Lukas on nende kohta öelnud järgmist:

Kaks neist ("Der Graf bot seine Schätze mir" / "Saks pakkus rikkust minule” ja "Mein! lobt mir doch nur nicht die Nacht!" / "Oh ärge kiitke mulle öö") olid Johann Adam Hilleri (1728-1804) koomilisest ooperist "Die Jagd" (esietendus 1770. aastal) pärit aariad. Kolmas almanahhi eestikeelne värsstekst oli anonüümne pastoraal pealkirjaga "Tomas ja Liso". Võib oletada, et eestikeelseid laule loodi avaldatust rohkem, sest almanahhi eessõnas vihjatakse suurema kogu avaldamise võimalusele (Albrecht [1779]: 5). (Lukas 2019: 868)

Huvitav on seejuures, et Recke ja Napiersky ei maini maakeelseid luuletusi ei Johann Friedrich Ernst Albrechtiga seoses, kelle seost "E(h)stländische Blumenlesega" ei tooda isegi esile (Recke \& Napiersky 1827, I: 31), ega ka tema naise Sophie Albrechti puudutavas leksikoniartiklis, kelle puhul luulealmanahhi on küll mainitud (Recke \& Napiersky 1827, I: 31); viide eestikeelsetele luuletustele puudub ka Friedrich Gustav Arveliuse artikli juures, kelle seos Eestimaa Blumenlesega on esile toodud (Recke \& Napiersky 1827, I: 50). Tekib kahtlus, kas Recke ja Napiersky neid eestikeelseid luuletusi üldse lähemalt tundsid, näinud olid; igatahes oma leksikonis nende mainimiseks sobivat paika ei paista nad leidnud olevat.

Toomase ja Liiso laul 1779. aastakäigu "Blumenleses" tuletab aga meelde teist Grahli 1784. aasta noodiraamatus ilmunud eestikeelset luuletust, mida Jaan Roos nimetas - kevadlaulu "Liesole", mille autorina Grahl mainib teist Eestimaa daami kui Tiio-laulu oma (Roos 1939: 165). Mõlemal juhul on tegemist pastoraalsete tekstidega: esimeses püüab karjane Tomas veenda tüdruk Lisot, et see talle anduks; teises pöördub Lieso poole lüüriline mina, kel paistavad olevat sarnased kavatsused Toomaga (vt kolmandat salmi):

\section{Lasse meid ka rõmo maitsta}

Kewadesse aia sees!

Vaat! ei au, ei rikkus seisa

Selle vasto ellades.

Mõtle! ruttes lennab ta

Meie nore aega.

(Roos 1939: 165)

Jaan Roos arvas, et selle laulu näol on tegu algupärandiga, kuid Liina Lukas on näidanud, et ka sellel laulul oli saksakeelne algversioon (Lukas 2019: 
869). Ta lähtub siin Johann Christoph Petri raamatus "Estland und die Esten" ("Eestimaa ja eestlased") 2. köites lk 70-71 ilmunud sama luuletuse eesti- ja saksakeelsest rööptekstist, millele eelneb Petri märkus: “Järgneva laulu loojaks on sakslane" (Folgendes Lied ist von einem Deutschen Verfasser" [minu esiletõst], Petri 1802, II: 70). Seega jääb mulje, et ka selle laulu on algselt kirjutanud sakslasest meesautor, kelle laul on eesti keelde tõlgitud. Kui uskuda Grahli, siis ühe Eestimaa daami poolt. Mis viib mõttele, et naistõlkija võis olla ka "Eestimaa poeetilises antoloogias" avaldatud teistel eestikeelsetel luuletustel-tõlgetel. Eestikeelsete tekstide naisautorlusele resp. -tõlkija(te)le võib viidata ka nende tekstide täielik anonüümsus. Anonüümseid tekste leidub selles luulealmanahhis teisigi, kuid enamasti on tekstid varustatud vähemasti initsiaalidega, mille tagant on Dirk Sangmeister suutnud tuvastada (kui jätta kõrvale rida Sophie Albrechti initsiaalide all avaldatud luuletusi) eranditult meesautoreid (paljud autorid on siiski tänini tuvastamata). 18. sajandi viimasel veerandil oli tavaline, et naised, juhul kui nad trükiavalikkuses üldse üles astusid, tegid seda anonüümselt, seda isegi väga kõrgest soost autorid nagu Kuramaa hertsoginna Benigna (1703-1782), kes avaldas 1777. aastal esimese baltisaksa naisena luulekogu. Anonüümsed olid ka Kuramaa ja Liivimaa aadlidaamide luulekogud, mis järgnesid 1780. aastate alguses. Alles 1790. aastal ilmus esimene balti naiste luulekogu, mille puhul oli kasutatud autorite täisnime. Üsna kindlad saame küll olla vaid Grahli 1784. aasta noodiraamatu laulude eestikeelsete laulude sünnis siinsete Eestimaa daamide vahendusel.

\section{Tiio ja Liiso - kes olid Grahli noodiraamatule eestikeelseid tekste loonud daamid?}

Kes need daamid olid? Kindlaid nimesid on siinkohal väga keeruline välja pakkuda, praeguse seisuga me neid veel ei tea. Võib vaid aimata, et nad olid kuidagi seotud tõenäoliselt Hans Wenzel von Tiesenhauseni perekonnaga ja tundsid arvatavasti ka saksa heliloojat Grahli. Võib-olla olid nad tuttavad ka Sophie Albrechti ja tolle abikaasaga, igatahes paistab Albrechtide ja "Blumenlesesid" ümbritsenud seltskonnaga olevat olnud kontaktis Grahl ise, ehkki võib-olla kaudselt: tema 1784. aasta noodiraamatu levitajana Tallinnas on muu hulgas mainitud nii Albrechti raamatukauplust kui ka advokaat (Martin Heinrich) Arveliust, "Blumenlesedes" Sembardi nime all ülesastunud Friedrich Gustav Arveliuse venda (Revalische Wöchentliche Nachrichten, 21.08.1783). Sophie Albrecht on oma luuletusi Ottilie von Tiesenhauseni kõrval pühendanud veel mitmele Eestimaa naisele, nt oma "Luuletuste ja näidendite" esimeses osas kellelegi Helene von Bielskyle (An Fräulein Helene von Bielsky. Im November 
1778 / "Preili Helene von Bielskyle. Novembris 1778", lk 47 = H. v. B. - Ehstländische poetische Blumenlese für 1779 [1779]: 32-33) ja Ernestine von Hastferile (An Fräulein Ernestine von Hastfer bey Uebersendung einiger Früh-Blumen. Im März 1779 / "Preili Ernestine von Hastferile mõningate priimulate läkitamisel. Märtsis 1779", lk 21). Viimase isikut ei ole suutnud tuvastada ei mina ega Sangmeister, sellise eesnimega naist vaadeldavast perioodist balti aadlileksikonist ei leia, ka ei aita selle nime osas edasi veeb. Helene von Bielsky nime ümber on aga teatavat segadust. York-Gothart Mix, Felix Köther ja Christina Kandler 2018: 106 on pakkunud tema eluaastateks 1764-1824. Dirk Sangmeiser arvab, et luuletuse adressaat Helene von Bielsky oli üks (Kadrina kihelkonna) Vatku (Wattküll) mõisa omaniku Bernhard Georg von Bielsky tütardest, keda Albrechtide luulealmanahhile kaastööd teinud Friedrich Johann Assmuth aastatel 1776-1778 õpetas (Sangmeister 2011: 446). Kadrinaga seoses leiame Sophie Helene von Bielsky nimelise naise, kelle eluaastateks pakub Geni aga 1759-1821 (GHbR, Teil Estland, III: 360 on tema sünniaastaks pakkunud küll 1764 nagu Mix jt, kuid see on teatavat kõhklust kinnitavates nurksulgudes, surmaaeg on sama mis Genis (1821), mis pakub täpseks sünniajaks 6. märts 1759). Sünnikoha osas pole selgust, kuid teada on, et ta suri Keila kihelkonnas, tema Tallinnast pärit isa Berend Johann aga Kadrina pastoraadis ning et Helenel oli mitu Valtus sündinud õde ja noorem vend, kes kandis Berend Georgi nime (https://www.geni.com/people/Sophie-Helene-vonBielsky/6000000024338667861 [02.11.2021]). Pole aga teada, kas Helene von Bielsky kirjutas või tõlkis, temale pühendatud luuletus on ülistus õidepuhkevale noorele põhjamaa naisele.

Sophie Albrechti 1781. aasta luuletuste ja näidendite kogu esimese osa suurima kummarduse osaliseks sai aga Dorothea Tideböhl (snd Kelch) Tallinnast, kellele Albrecht oma luulekogu pühendas ja keda Sangmeister on pidanud Sophie Albrechti Eestimaa-perioodi üheks lähedasemaks sõbratariks (tema kohta vt Sangmeister 2011: 445-446). Tegemist on Tallinna Toomkooli õpetaja Johann Christian Tideböhli abikaasa Anna Dorothea Tideböhliga (snd Kelch, lesestunud Harpe, 1743-1807, vt https://www.geni.com/people/Anna-DorotheaKelch/6000000012706548373 [2.11.2021]), keda Sophie Albrechti esikkogu tellijate nimekirjas on nimetatud ka Madame Tideböhliks. Lisaks on tellijate seas mainitud Demoiselle Tideböhli. See oli Johann Christiani ja tolle samuti Toomkooli õpetajast venna Georg Gottliebi õde Anna Dorothea (1747-1803, vt https://www.geni.com/people/Anna-Dorothea-Sabler/6000000027155991627 [2.11.2021]). Viimane abiellus 1790. aastal Haljala pastori Thomas Sableriga, kes oli varem olnud abielus Anna Dorothea (snd Kelch) õe Johanna Julianaga, kes suri 6.03.1778 (Aarma 2007: 228). Muide, esimesest abielust sündis Thomas Sableril 1776. aastal poeg Georg Christian, kellest sai hiljem esimene Daniel 
Defoe romaani "Robinson Crusoe" tõlkija eesti keelde. Kuigi tõlge ei ilmunud ja ka käsikiri on kadunud (Aarma 2007: 228), annab see märku estofiilsetest huvidest Sablerite perekonnas. Juba Thomas Sabler ise avaldas 1779. aastal eestikeelses jutluseraamatus seitse jutlust (Aarma 2007: 228). Lisaks Anna Dorotheale oli vendadel Tideböhlidel veel üks õde, Beata Christine, kes oli "Blumenlesede" ja Sophie Albrechti esikkogu ilmumisajaks juba abielus Juuru Mihkli koguduse pastori Friedrich Gustav Knüpfferiga, kelle pojast, 1777. aastal sündinud Arnoldist sai hiljem tuntud estofiil, kes lähemat tutvustust ei vaja. Asjaolule, et side Kelchide, Tideböhlide, Knüpfferite ja Sablerite vahel oli tihe, viitab seegi, et Georg Christian Sabler abiellus hiljem Arnold Knüpfferi õe Johanna Julianaga (Aarma 2007: 228), kes paistab eesnime olevat saanud suisa oma hilisema mehe varalahkunud emalt. Suhtlus Tideböhlide ja Haljala vahel jäi ilmselt aktiivseks ka pärast Johanna Juliana (snd Kelch) surma.

Õed Kelchid olid sündinud ja ilmselt vähemasti lapsepõlve veetnud Türil, kus nende isa Marcus Kelch (1712-1756) pidas pastoriametit. Nende ema, Kullamaalt pärit Anna Margaretha Bartsch (snd von Gersdorff) paistab olevat olnud isegi aadlipäritolu (Aarma 2007: 228). Enne Johann Christian Tideböhli oli Anna Dorothea (snd Kelch) olnud abielus veel Tallinna Toomkoguduse ülempastori Wilhelm Christian Harpega (Adelheim 1929: 85-86; https://www.geni. com/people/Wilhelm-Christian-Harpe-I/6000000012705762923 [2.02.2021]), kelle isa, mõisainspektor Otto Wilhelm Harpe, oli Ohtu, Ulvi ja Tudu (sic!) mõisa omanik ja ema Euphrosyne Elisabeth tuntud krooniku, Järva-Jaani ja Viru-Nigula pastori Christian Kelchi tütar. Mees suri juba 1767. aastal ja jättis Anna Dorotheale poeg August Wilhelmi ja kolm kasulast. 1769. aastal sõlmitud abielust Johann Christian Tideböhliga sündis ilmselt juba pärast Albrechtide Eestimaal viibimist tütar Anna Julia (hiljem von Timroth).

Kas Anna Dorothea (snd Kelch) luuletas ja veel eesti keeles? 1780. aastale pühendatud "Blumenleses" leidub luuletus "Dorotheapäeval 1779" (Am Dorotheentage 1779; lk 94-96), mis algab pöördumisega sõbratari poole, kel palutakse sel päeval “oma lüüra muusadele kinkida” (Schenke deine Leyer heut' den Musen: Estländische poetische Blumenlese für 1780 [1779]: 94), mis lubab oletada, et arvatavasti oli sõbratari näol tegemist "muusade teenijaga", siinses kontekstis ilmselt luuletava naisega (näiteks leiame lüüraga naise kujutise Kuramaa luuletajate Elisa von der Recke ja Sophie Schwarzi 1790. aasta ühise luulekogu tiitellehelt), kuid hiljemalt teisest salmist on selge, et oma vastse abikaasa poole pöördub mees. Allkirjastatud on luuletus kujul $\mathrm{E}^{* *}$ (Ehemann? ee 'abikaasa'), nii et kirjutajaks võiski olla adressaadi mees, kuid välistatud ei ole ka Sophie Albrechti autorlus, sest ta kirjutas paljude initsiaalide all ja idealiseeris siin ehk ülitundelises laadis oma sõbratari abielu. Oma luulekogus on ta pühendanud igatahes luuletusi ka vendadele Tideböhlidele (vt Sangmeister 
2011: 446). Me ei saa muidugi olla päris kindlad, et luuletuse adressaat on just Anna Dorothea (snd Kelch), liiga mitmeid võimalikke Dorotheasid tuleb siin kõne alla. On ka võimalik, et silmas ei peetudki otseselt sõbratari nime. Püha Dorothea, kelle päeva tähistati 6. veebruaril (eesti rahvakalendris tuntud toorapäeva nime all), oli muu hulgas ka lihtsalt vastabiellunute kaitsepühak (vt https://www.heiligenlexikon.de/BiographienD/Dorothea.htm [2.11.2021]. Sel juhul mainitud Tideböhli-naised luuletuse adressaadina pigem kõne alla ei tule, sest Anna Dorothea (snd Kelch) oli (teist korda) abiellunud juba kümnend tagasi ja Anna Dorothea (abielus Sabler) abiellus alles tosin aastat hiljem. "Muusade teenijale" pühendatud luuletuse adressaat oli tõenäoliselt pigem keegi, kes oli abiellunud alles 1779. aasta paiku.

Veidi kahtlust äratab ka see, kas Grahl oleks nimetanud Tideböhlide Anna Dorotheasid Eestimaa daamideks, kuivõrd nii tähistati tavaliselt aadlisoost naisi, abielus kodanlasenaisi kutsuti madame'iks ja vallalisi (ma)demoiselle'iks, nii nagu on näha ka Sophie Albrechti luule- ja näidenditekogu tellijate nimekirjast. Samas Anna Dorothea (snd Kelch) ema oli nagu teame aadlisoost ja ta ise ülimalt mõjukate meeste naine, nii et ehk võis pidada teda daami nimetuseks piisavalt auväärseks isikuks. Kuivõrd tegemist oli maa-pastori tütrega, võib ka eeldada, et tal oli piisavalt võimalust puutuda kokku eesti keelega. Haljala pastoriproua õde pühendamas eestikeelset luuletust samas kihelkonnas elanud Sauste mõisaprouale, kellega tal võis olla ühiseid sõpru-tuttavaid (lisaks Sophie Albrechtile ka endise mehe pere ja lähiringi kaudu), see ei kõla täiesti ilmvõimatult?! Ka tuleb kõne alla, et Anna Dorothea (snd Kelch) tundis kõiki arutluse all olnud võimalikke Tiio- või Roosi-laulu adressaate, nii Sauste mõisniku õde ja naist kui ka Jacobine Henriette von Schwengelmit kasvõi lihtsalt Toomkoguduse kaudu, sest ka Tideböhlid olid selle koguduse liikmed (vrd TLA.237.1.26: 220; Anna Dorothea (snd Kelch) nr 3675; Anna Dorothea Tideböhl (abielus Sabler) nr 3674 ja 3676; Jacobine Henrietta von Schwengelm TLA.237.1.26: 200, nr 3233).

Kuni meil ei ole kindlamaid tõendeid, jääb võimalik seos Tideböhlidega siiski vaid spekulatsiooniks ja otsinguid tuleb jätkata. Seda ilmtingimata ka aadlidaamide seas, kes võisid eesti keele oskuse omandada juba ammedelt. Täpsemate viidete puudumisel sarnaneb see hetkel küll nõela otsimisega heinakuhjast. Selleks, et midagigi leida, tuleks lähemalt kaardistada Sauste Tiesenhausenite suhtlusvõrgustik, milleks pankrotimenetluse ja muud säilinud materjalid pakuvad ohtrasti võimalusi, ilmselt oleks abi sellestki, kui püüda uuesti luubi alla võtta ka "Blumenlesede" kaastööliste ring, et saada selgem pilt võimalikest kirjutajatest ja kirjanduslikest suhtevõrgustikest Eesti alal 18. sajandi viimasel veerandil. Sellest artiklist võtkem aga kaasa teadmine, et Roosi-laulu taga seisis tõenäoliselt Lääne-Virumaa Haljala kihelkonna Sauste 
mõisnik Hans Wenzel von Tiesenhausen, kes oli arvatavasti ka "Eestimaa poeetilise antoloogia" 1780. aastakäigus ilmunud v. Tiesenhauseni allkirja kandva luuletuse autor.

\section{Tänusõnad}

Artikli valmimist on toetanud Euroopa Liidu Regionaalarengu Fond (Eestiuuringute Tippkeskus) ning see on seotud Eesti Haridus-ja Teadusministeeriumi uurimisprojektiga PRG1106 "Lüürilise luule tegur väikeste kirjanduste kujunemisel” ja Tallinna Ülikooli Akadeemilise Raamatukogu kultuuriloolise koguga.

\section{Arhiiviallikad}

\section{Rahvusarhiivis}

EAA.3.1.630 Akte in Klagesachen des Adjunkts Reinhold Johann Zoege von Mannteuffel wider den Kapitän Hans Wenzel von Tiesenhausen wegen Schuldforderung, 28.09.1776.

EAA.3.1.661 Akte in Klagesachen des Kapitäns Hans Wentzel von Tiesenhausen wider den Hakenrichter Jacob Johann von Tiesenhausen wegen Arrendeschuld, 20.03.17809.09.1780.

EAA.7.1.764 Originalia der respectiven Herr Creditorum des Hans Wenzel von Tiesenhausen, 23.01.1784-1786.

EAA.858.1.1423 Kommunikate der Administrativbehörden und Gerichtsbehörden betreffend Verbotlegungen auf Vermögen und Aufhebung derselben, 02.1800.F

EAA.858.1.1478 Proklamationsgesuche von Privatpersonen und Proklamen betreffend Kauf und Verkauf der Güter, Konvokation der Kreditoren, 1770 [Saarnakõrve mõis].

EAA.858.1.2152 Akte in Subhastationssachen des Kapitäns H. W. von Tiesenhausen betreffend die Güter Saup [Sauß] und Tiddo [Tuddo], 23.11.1780-1781.

EAA.858.2.4378 Estländisches Oberlandgericht. Akte in Konkurssachen des Kapitäns Hans Wentzel von Tiesenhausen, [alustatud 9.06.]1781-1789.

EAA.1864.2.IV-1 1782. aasta hingeloend: Jõelähtme, Harju-Jaani, Kuusalu, Jüri, Kose, Rapla kihelkond [Saarnakõrve mõis].

EAA.1864.2.IV-4 1782. aasta hingeloend: Haljala, Kadrina, Rakvere [Sauste mõis].

EAA.1864.2.IV-5 1782. aasta hingeloend: Iisaku, Simuna, Viru-Jaagupi, Väike-Maarja [Tudu mõis].

EAA.1215.2.5 EELK Kose kogudus: Sünni-, abielu ja surmameetrika; EAA.1215.2.5; $1760-1778$. 
EAA.1226.2.4 EELK Jõhvi kogudus: Sünni-, abielu-, surmameetrika ja andmed koguduse tegevuse kohta (saksa pihtkond), 1751-1803.

EAA.1226.2.6 EELK Jõhvi kogudus: Sünni-, abielu-, surmameetrika, 1782-1805.

EAA.3114.2.3 EELK Viru-Jaagupi kogudus: Sünni-, abielu-, surmameetrika, 1743-1787.

EAA.3057.2.2 EELK Rakvere kogudus: Sünni-, abielu-, surmameetrika ja andmed koguduse tegevuse kohta; 1772-1795.

EAA.4187.1.3796 Virumaal asuva Tudu mõisa kinnistu nr. 144 toimik, 1811-1937.

TLA.237.1.23 Tallinna Toomkogudus: Kirchenbuch: Verzeichnis der Copulierten. Verzeichnis der Getauften. Verzeichnis der Verstorbenen, 1724-1758.

TLA.237.1.26 Auszüge aus den Kirchenbüchern des Estländischen Consistorialbezirks. Bis zum Jahre 1913. II.Theil. Die Ritter u. Dom Kirche in Reval. Zusammengestellt von Wold. B. Hoyningen Huene. (mit einer kurzen Einleitung über die Domkirche), 1913.

\section{Internetiallikad}

\section{(kontrollitud 25.11.2021)}

EEVA = Eesti vanema kirjanduse digitaalne tekstikogu (https://utlib.ut.ee/eeva/index. php?lang=et\&do=autor_search)

Geni = A My Heritage Company (https://www.geni.com/worldfamilytree)

Heiligenlexicon (pühakute leksikon) = Ökumenisches Heiligenlexicon (https://www. heiligenlexikon.de/BiographienD/Dorothea.htm\#google_vignette)

TLÜAR = Tallinna Ülikooli Akadeemiline Raamatukogu, rahvusbibliograafia isikud (http://isik2.tlulib.ee/index.php?m=browse\&tag=65)

\section{Kirjandus}

Aarma, Liivi 2007. Põhja-Eesti vaimulike lühielulood 1525-1885. Tallinn: [G. ja T. Aarma Maja OÜ].

Adelheim, Georg 1929. Revaler Ahnentafel. Eine Fortsetzung der Laurenty'schen “Genealogie der alten Familien Revals”. Erste Lieferung. Reval: Wassermann.

[Anon.] 1787. Minno Römuks olli Rosi. Findeisen, Friedrich Gotthilf (toim) 1787. Lesebuch für Ehst- und Livland. Kd. 5. Oberpahlen: [Grenzius und Kupzau], lk 472.

Albrecht, Sophie 1781. Gedichte und Schauspiele. 1. kd. Erfurt: Albrecht und Co.

Ehstländische poetische Blumenlese für das Jahr 1779. [1779] Wesenberg: Albrecht und Co.

EKA 1965 = Vinkel, Aarne (toim) \& Sõgel, Endel (peatoim) 1965. Eesti kirjanduse ajalugu viies köites. 1. kd. Esimestest algetest XIX sajandi 40-ndate aastateni. Eesti NSV Teaduste Akadeemia, Keele ja Kirjanduse Instituut. Tallinn: Eesti Raamat. 
Estländische poetische Blumenlese für 1780. [1779] Reval, Leipzig: Albrecht und Co.

Garber, Klaus (toim) 2003a. Handbuch des personalen Gelegenheitsschrifttums in europäischen Bibliotheken und Archiven. 7. kd. Reval - Tallinn: Estnische Akademische Bibliothek - Eesti Akadeemiline Raamatukogu, Estnisches Historisches Museum - Eesti Ajaloomuuseum, Estnische Nationalbibliothek - Eesti Rahvusraamatukogu, Revaler Stadtarchiv - Tallinna Linnaarhiiv. Mit einer bibliotheksgeschichtlichen Einleitung und einer kommentierten Bibliographie von Martin Klöker. Garber, Klaus; Klöker, Martin; Beckmann, Sabine; Anders, Stefan (toim). Hildesheim \& Zürich \& New York: Olms-Weidmann.

Garber, Klaus (toim) 2003b. Handbuch des personalen Gelegenheitsschrifttums in europäischen Bibliotheken und Archiven 8. kd. Dorpat - Tartu: Universitätsbibliothek Ülikooli Raamatukogu, Estnisches Literaturmuseum - Eesti Kirjandusmuuseum, Estnisches Historisches Archiv - Eesti Ajalooarhiiv. Mit einer bibliotheksgeschichtlichen Einleitung und einer kommentierten Bibliographie von Martin Klöker. Garber, Klaus; Klöker, Martin; Beckmann, Sabine; Anders, Stefan (toim). Hildesheim \& Zürich \& New York: Olms-Weidmann.

Gottzmann, Carola \& Hörner, Petra (toim) 2007. Schlegel, Christian Hieronymus Justus. Lexikon der deutschsprachigen Literatur des Baltikums und St. Petersburgs. Band 3 N-Z. Berlin \& New York: de Gruyter, lk 1143-1144.

Grahl, A. T. 1783. Bekanntmachung. Revalische Wöchentliche Nachrichten, 21.08.1783.

GHbR = Genealogisches Handbuch der baltischen Ritterschaften: Teil Estland. [kd. 1-3], im Auftrage des Verbandes des estländischen Stammadels bearbeitet von O. M. von Stackelberg. Görlitz: Verlag für Sippenforschung und Wappenkunde C. A. Starke, 1929-1931.

Genealogisches Handbuch der baltischen Ritterschaften. Teil Livland. 1. kd., herausgegeben vom Verband des livländischen Stammadels; bearbeitet von Astaf v. TranseheRoseneck. Görlitz: Verlag für Sippenforschung und Wappenkunde C. A. Starke [1929].

Hagemeister, Heinrich von 1836. Materialien zu einer Geschichte der Landgüter Livlands. 1. osa. Riga: Franzen.

Hagemeister, Heinrich von 1843. Erste Fortsetzung von des Herrn Hofraths von Hagemeister Materialien zur Gütergeschichte Livlands. Riga: Kymmel.

Heinmaa, Heidi 2017. Muusikaelu Tallinnas 18. sajandil. Tallinn: Eesti Muusika- ja Teatriakadeemia.

Jakobson, T. 1937. Veel vanemaist noodiraamatuist. Postimees, nr 224, lk 6.

Jürjo, Indrek 2004. Liivimaa valgustaja August Wilhelm Hupel, 1737-1819. Tallinn: Riigiarhiiv.

Kampmann, Mihkel 1912. Eesti kirjanduseloo peajooned. 1. jagu. Tallinn: Busch.

Kaur, Kairit 2013. Dichtende Frauen in Est-, Liv- und Kurland, 1654-1800. Von den ersten Gelegenheitsgedichten bis zu den ersten Gedichtbänden. Dissertationes litterarum et contemplationis comparativae universitatis Tartuensis 11. Tartu: University of Tartu Press.

Lukas, Liina 2019. Eesti ja läti luule sünd saksa laulu vaimust II. Keel ja Kirjandus 11, lk 868-878 (https://keeljakirjandus.ee/ee/uncategorized/eesti-ja-lati-luule-sund-saksalaulu-vaimust-ii/ - 3. november 2021). 
Meusel,Johann Georg 1796.Dasgelehrte TeutschlandoderLexikonderjetztlebendenteutschen Schriftsteller. Angefangen von Georg Christoph Hamberger, ... Fortgesetzt von Johann Georg Meusel, ... 5., durchaus vermehrte und verbesserte Auflage. Lemgo: Meyer. Bd. 2.

Mix, York-Gothart 1987. Die deutschen Musenalmanache des 18. Jahrhunderts. München: Beck.

Mix, York-Gothart \& Köther, Felix \& Kandler, Kristina 2018. Die Kalender-, Almanachs-, und Taschenbuchliteratur Estlands, Livlands und Kurlands (1700-1830). Analytische Bibliographie. Teil I. Archiv der Geschichte des Buchwesens, Bd. 73, lk 1-143.

Recke, Johann Friedrich von \& Napiersky, Karl Eduard (toim) 1827-1832. Allgemeines Schriftsteller- und Gelehrten-Lexikon der Provinzen Livland, Ehstland und Kurland. $4 \mathrm{kd}$. Mitau: Steffenhagen und Sohn.

Paškevica, Beata 2011. Schillers Drama Die Räuber in der Übersetzung eines lettischen Leibeigenen. Eine eigenartige Rezeptions- und Inspirationsgeschichte. Bosse, Heinrich \& Elias, Otto-Heinrich \& Taterka, Thomas (toim). Baltische Literaturen in der Goethezeit. Würzburg: Königshausen \& Neumann, lk 291-302.

Petri, Johann Christoph 1802. Ehstland und die Ehsten, oder historisch-geographischstatistisches Gemälde von Ehstland. Ein Seitenstück zu Merkel über die Letten. Kd. 2. Gotha: Ettinger.

Ridala, Villem 1924 [1925]. Eesti kirjanduse ajalugu koolidele. I jagu. 2., parandatud ja täiendatud tr. Tartu: Noor-Eesti.

Roos, J. 1939. Ühest vanast noodiraamatust. Eesti Kirjandus 4, lk 161-166.

Sangmeister, Dirk 2011. Von Blumenlesen und Geheimbünden. Die Jahre von Johann Ernst Albrecht als Verleger in Reval und Erfurt. Bosse, Heinrich \& Elias, Otto-Heinrich \& Taterka, Thomas (toim). Baltische Literaturen in der Goethezeit. Würzburg: Königshausen \& Neumann, lk 411-487.

Schlegel 1788. Etwas über Form, Geist, Charakter, Sprache, Musik und Tanz, der Ehstnischen Nation. Beyläufig etwas über die Schönheit der teutschen Damen in Ehstland. An einen Freund im Jahr 1783. Wieland, Christoph Martin (toim). Der Teutsche Merkur, Bd 2. Weimar: [s. n.], lk 331-347, 404-433.

Suits, Gustav \& Lepik, Märt (toim) 1932. Eesti kirjandusajalugu tekstides. Tartu: Akadeemiline Kirjandusühing.

\section{Summary}

\section{Tio, Rosi, Li(e)so and Tomas: In search of authors publishing poems in Estonian around 1780}

\section{Kairit Kaur}

Research Fellow

University of Tartu

Tallinn University Academic Library

Keywords: Ehstländische poetische Blumenlese, Andreas Traugott Grahl, local tongue, poetry, Hans Wenzel von Tiesenhausen, Ottilie von Tiesenhausen, women 
According to Recke and Napiersky, the first poems in Estonian from the pen of a woman were allegedly published in 1779, in the sheet music book Oden und Lieder in Musik gesetzt by Andeas Traugott Grahl, a private tutor in the Governorate of Estonia, but unfortunately it is not preserved. More luckily another sheet music book by him, Lieder und Handsachen für das Klavier und den Gesang, published in Leipzig in 1784, was available to the researchers before World War II. Two poems by Estonian ladies were published there: Tio, tassane ja helde and Liesole. A variant of the Tio-poem (the socalled Rosi-poem) was published in 1787 in the 5th volume of the reader Lesebuch für Ehst- und Livland by Friedrich Gotthilf Findeisen in Oberpahlen (Põltsamaa) in Livonia, and a year later, in 1788 , in a longer version in the German literary magazine Der Teutsche Merkur. To the latter, the poem was mediated by Christian Hieronymus Justus Schlegel, a private tutor in Estonia from 1780 to 1782, and then pastor, who left Estonia in 1783. However, he did not ascribe the Rosi-poem to an Estonian lady, but to a gentleman, von Tiesenhausen of Saus, who wrote the poem on the occasion of the passing of his wife.

There are several manors called Saus or Sauß in Estonia. Traditionally the Rosipoem has been ascribed to Ber(e)nd Heinrich von Tiesenhausen of Groß-Sauß (Sausti or Kaarepere). But there was another manor called Sauß (Sauste) near Wesenberg (Rakvere), which belonged to captain Hans Wen(t)zel(l) von Tiesenhausen from 1779 to 1781.

Based on several sources, this paper brings forth arguments to support the thesis that the gentleman, von Tiesenhausen, mentioned by Schlegel was actually Hans Wenzel von Tiesenhausen. This man was probably also identical with the captain von Tiesenhausen, whom Grahl has named as his employer in the subscription call of the Lieder und Handsachen. According to Professor Gustav Suits, Grahl acted as a private tutor somewhere near Wesenberg.

The paper also suggests that H. W. von Tiesenhausen was the author of the poem Der Client an seinen Sachwalter, published in the muses almanac Estländische poetische Blumenlese for 1780. Earlier this poem has been ascribed to Johann Georg von Tiesenhausen from Northern Latvia.

Dirk Sangmeister has guessed that the Albrechts who published the almanac mentioned the name Wesenberg on the cover of the first issue of their periodical (for 1779) in honour of the owner of the Wesenberg manor, judge Jakob Johann von Tiesenhausen and his family, with whom Sangmeister believes the Albrechts stood in a cordial relationship as Sophie Albrecht dedicated several poems to a certain Ottilie von Tiesenhausen. The last one lets us know that on the 9th of June 1781, the news of the death of her beloved friend had reached Sophie Albrecht.

The date 9th of June 1781 (due to calendar differences actually 11 days later) can also be found in the archival materials concerning H. W. von Tiesenhausen - on this day his bankruptcy proceedings were started. Already in January 1781 he had sold Sauß; in March 1781 his other manor - Tuddo (Tudu) - was sold too; these are likely the two manors mentioned in his German poem. The bankruptcy proceedings were evoked by a lawsuit, initiated in March 1780 by J. J. von Tiesenhausen, who from 1774 to 1780 rented his Wesenberg manor to his second cousin Hans Wenzel. From 1779 the latter had difficulties in paying the rent. As at the time of the publication of Estländische poetische Blumenlese it was H. W. von Tiesenhausen who was living in the manor of Wesenberg, the recipient of the poems by Sophie Albrecht was very likely his wife.

Neither the given nor the maiden name of this woman or her birth date and the exact death date are preserved. H. W. von Tiesenhausen mentions his wife without her name 
in his report to the court, Demüthigste Anzeige und Unterlegung der wahren Umstände meines gegenwärtigen unglücklichen und betrübten Schicksaals (The humblest report and interpretation of the true circumstances of my current unhappy and sad fate), signed 26 June 1781. It appears that his wife really died shortly before the composing of the report. Frau Capitainin Tiesenhausen has also been mentioned three times in the birth register of the Wesenberg church in 1777 as a godparent, one of the cases being as godmother of a girl, whose mother was the sister of G. W. von Schwengelm, the employer of mister Schlegel, who mediated the Rosi-poem to the Teutsche Merkur!

The paper also presumes that the ladies mentioned by Grahl could have been translators and guesses who these women were, but as we lack confirmed proof, the investigation must continue.

Kairit Kaur on Tartu Ülikooli ja Tallinna Ülikooli Akadeemilise raamatukogu teadur. Ta on õppinud saksa keelt ja kirjandust ning kaitsnud doktorikraadi võrdlevas kirjandusteaduses. Tema huvikeskmes on baltisaksa kirjandus ja kultuur, selle suhted Lääne-Euroopaga, maailmakirjanduse tulek Eestisse ja siinse regiooni varane naiskirjandus.

Kairit Kaur is research fellow at the University of Tartu and Tallinn University Academic Library. She has studied German language and literature and defended her thesis in comparative literature. Her main focus of interest is on Baltic German literature and culture, their relations to Western Europe, the arrival of world literature to Estonia and the early women's writing in this region.

kairit.kaur@ut.ee, kairit.kaur@tlulib.ee 